\title{
SELLING PLUTOLOGY: CORRESPONDENCE RELATING TO THE FAILURE OF AUSTRALIA'S FIRST ECONOMICS TEXT
}

\author{
Gregory C. G. Moore*
}

\begin{abstract}
I know not what accidental circumstance, the distant residence of the author, or the unfortunate selection of a title, for instance, has diverted attention from the singular excellence and independence of his work. W.S. Jevons on W.E. Hearn's Plutology (1871: 265).
\end{abstract}

William Edward Hearn's Plutology was printed in Melbourne by Wilson and Mackinnon in 1863 and then bound and distributed in Melbourne in the same year through the publishing house of George Robertson and in London in 1864 through the publishing house of Macmillan and Co. Historians of economic thought have correctly portrayed this book as one of the most important economic tracts to appear in the Australian colonies during the nineteenth century. Admittedly many of these same historical authorities have followed the lead of Hearn's most important and meticulous biographer, J.A. La Nauze (1949), in questioning the originality of many of the doctrines contained in Plutology, but at no time do they explicitly qualify the received view that this book was one of Australia's most important contributions to the field of political economy during the Victorian age (Copland 1935:9; Hutchison 1953:64; Blainey 1957:49-1; Green 1961:321; La Nauze 1972; Groenewegen and McFarlane 1990:2,51). ${ }^{1}$ The prevailing opinion that the publication of Plutology signified a highpoint in the pioneering stage of Antipodean political economy rests partly on direct comparisons of this text with the usual dross that was passed off as economic analysis in the colonies at this time and partly on the glowing (and now commonly cited) references to this text made by three of the most important late-Victorian political economists: William Stanley Jevons, Alfred Marshall and Francis Ysidro Edgeworth. Jevons provided an early 'anonymous' notice of Plutology in The Spectator in which he emphasised its innovative focus on the way effort is harnessed to satisfy human wants (5 March 1864); he praised it again in The Coal Question for its soundness and originality ([1865] 1906:168); and, most significantly, he magnanimously devoted an entire section of the concluding chapter of the Theory of Political Economy to spelling out its pathbreaking qualities ([1879] 1931:273; see also various entries in Black 197381). Marshall, on the other hand, advised the future Mrs Marshall and other students who attended his Cambridge lectures in the early to mid-1870s to read Plutology as an introductory text (1947:20); he (with Mrs Marshall) made reference to Hearn in a footnote in Economics and Industry as one of a number of economists who adhered to the notion that wages were determined by demand and supply (1879:205n); and he argued in all of the many editions of the Principles that Plutology was at 'once simple and profound' ([1890] 1920:91). Edgeworth echoed these views in his entry on Hearn for Palgrave's Dictionary of Political Economy, where he wrote that Plutology was a model of classical style and that, 'like Hermann or Ricardo, Hearn holds an intermediate course between the highest 
abstraction and mere information, neither soaring to mathematical analysis nor creeping among historical details' (1896:295).

The purpose of this note is to draw upon previously unpublished correspondence relating to the publication of Plutology to demonstrate that although this book was indisputably the most important economic tract to appear in Australasia in the Victorian age, it could in no way be described as a publishing success. ${ }^{2}$ Indeed, it is clear from the correspondence in question that even though this publication eventually received praise from the leading political economists of the late Victorian period, and even though the nascent neoclassical theories contained within its covers probably had some influence on these scholars, the book itself was a spectacular publishing failure. The letters that are germane to this issue are reprinted in an appendix to this note and they predominantly consist of correspondence between Hearn and his English publisher, Alexander Macmillan, and between Hearn and his contemporaries sent via Macmillan. There are nine letters in total, and all are derived from the Hearn Papers held in the archives at Melbourne University and the Hearn Correspondence held in the manuscript section of the National Library of Australia. ${ }^{3}$ The first of these collections was purchased at auction from a Hearn heir in 1961 and the second was bought from the private collection of Sir John Ferguson in 1970, and consequently neither was presumably available to La Nauze when he undertook his painstaking research for his pioneering (though overly critical) account of Hearn's contributions to the discipline of political economy (1949). The only subsequent work in which reference is made to these manuscripts is La Nauze's later biographical sketch of Hearn for the Australian Dictionary of Biography (1972), in which he cites the Melbourne University archives in his bibliography, but does not draw upon them in any meaningful way. La Nauze's failure to utilise this primary source in this latter piece is something of a mystery, but it may have been due partly to his need to achieve the brevity required of a dictionary entry, partly to the fact that the entry was concerned with Hearn's life as a whole rather than solely with his career as a political economist, and partly to the fact that the letters contained in the Melbourne archives take on greater meaning only once they are placed alongside the letters from the National Library archives.

The letters themselves allow a number of conclusions to be drawn. First, Hearn's Plutology was a dismal failure in the marketplace. Macmillan held 500 copies of the book in 1864 and after two years only 87 had been sold and 37 had been given away (Letter 6). The sales were in fact so dismal that an embarrassed Macmillan delayed writing to Hearn to inform him of the book's progress in the marketplace: 'The real state of the case has been that its success has been so slight that I have felt reluctance in conveying to you the intelligence that can hardly do otherwise than disappoint you' (Letter 7). Second, Hearn and Macmillan unsuccessfully attempted to promote the book by sending complimentary copies both to scholars known to Hearn, and hence who were presumably predisposed to review the work, and to scholars who were then prominent in the field, such as John Stuart Mill. This was a common marketing practice in publishing circles at this time, as it is now, and it provides an indication of who may have read the work when it first appeared. The preponderance of Irish scholars amongst the letter writers (namely, John Kells Ingram, T.E. Cliffe Leslie, Arthur Housten, Neilson Hancock and T.W. Moffet) also demonstrates that the political economists with whom Hearn was acquainted consisted largely of those he had met in his years as a student at Trinity College, Dublin, and during his brief tenure as Professor of Greek 
at Queen's College, Galway, rather than the leading authorities in London and Cambridge (Letters 1, 2, 4, 5, 8, 9). ${ }^{4}$ Indeed, Macmillan attributes the slow sales of Plutology partly to Hearn's status as an 'outsider' from the Antipodes, and vainly inquires if he knows any reputable political economists whom he could ask to promote the book on his behalf. Third, the only political economist of note who volunteered to promote the book was Jevons, who had become a close friend of the Macmillan family and was then gaining fame from his book, The Coal Question (1865). Macmillan suggested to Hearn that he correspond with Jevons directly, and the passage from the The Coal Question in which Jevons 'spoke warmly' of Hearn's book was appended to the advertisements in the more influential newspapers and Macmillan's own magazine. Macmillan added, however, that the effect of Jevons's panegyric 'has been slight indeed, almost nothing, and this though Mr Jevons was in the meantime elected to the chair of Political Economy at Owens College Manchester, which ought to have added weight to his very favourable judgement' (Letter 7). Fourth, the leading authorities other than Jevons not only failed to review Plutology, but failed to respond to the personal appeals made by Macmillan to provide recommendations suitable for advertisements and what are now called dust-jacket 'blurbs'. In Macmillan's words: 'I have endeavoured to elicit opinions from such of the leading Political Economists to whom I sent copies, and whom I knew personally. The only definite one I got was verbally from a man of considerable weight in the current of opinion on such subjects in this country that he did not agree in Professor Jevons['s] estimate' (Letter 7)..$^{5}$ Fifth, due to the abject failure of Plutology in the marketplace, Macmillan was not prepared to handle Hearn's proposed book on the English constitution, which was eventually published as The Government of England (1867) by George Robertson in Melbourne and Longmans Green, Reader and Dyer in London. Indeed, no doubt with the success of Jevons's The Coal Question and John Elliot Cairnes's Slave Power (1862) uppermost in his mind, Macmillan suggested that Hearn instead write something more topical and relevant to the seat of Empire, even though he thought that this might be a difficult task to undertake from a distance in the colonies (Letter 7).

One can only speculate about the extent to which the poor reception of Plutology, as revealed by this correspondence, encouraged Hearn to direct his attention away from political economy to historical jurisprudence and colonial politics. It should also be noted that the existing secondary references indirectly bear out the main findings derived from this correspondence. It is known, for example, that Plutology received only four short anonymous reviews in the periodicals when it appeared in London in 1864. In addition to Jevons's positive notice for The Spectator (5 March 1864), the contributors to The Saturday Review (14 May 1864), The Athenaeum (4 June 1864), and The Reader (19 March 1864) all praised the book for its style and illustrations, but added that the work did not add much to a science that was largely settled. ${ }^{6}$ Thus, apart from Jevons's brief but glowing reference in The Coal Question in 1865, the main public accolades puffing the book that are normally cited by historians did not appear until well over a decade after the publication of the English edition. Specifically, Jevons's glowing reference to Plutology in the second edition of the Theory of Political Economy (the edition that most people read) appeared fifteen years after 1864; Marshall's frank endorsement of it in the Principles appeared twenty-six years after this date; and Edgeworth's high praise of it in Palgrave's Dictionary appeared a full thirty-two years after this date. Hearn was in fact dead by the time the last two of these 
famous references saw the light of day. Admittedly a few copies of Plutology may have been sold as the result of Marshall's private recommendation in the early-tomid 1870s that students read it as an introductory text, but even this advice was dispensed at least eight years after 1864. The sluggish sales in the English market were also probably replicated in the colonial market, although, again, there is only indirect evidence of this. It is known, for example, that Plutology grew out of Hearn's lectures entitled 'The General Principles of the Science, as contained in Mr Senior's Political Economy and Adam Smith's Wealth of Nations', which he delivered as the Professor of Modern History, Modern Literature, Logic and Political Economy at Melbourne University, and that the book was designed as an introductory text for those undergraduates who took the compulsory subject in political economy within the arts degree. There was, however, an extremely limited market for university texts in political economy at Melbourne University, which had an average of ten graduates from all its faculties in the first twenty years of its existence, and, indeed, the uncommercial nature of this limited market probably explains the need for a double issue of the work in Melbourne and London (see Groenewegen and McFarlane 1990:64n). Sales no doubt picked up slowly over the years as the number of undergraduates at Melbourne University increased. There is evidence that Hearn's successor, J.S. Elkington, used it as a text from 1876 until 1912, and that it continued to be a prescribed text until 1924, sixty-one years after its first publication (La Nauze 1949:19). It is likely that this small, but constant, colonial demand soaked up the remaining 500 copies of the London edition held by Macmillan, especially once the local 1863 edition had sold out. The need for a limited additional run of copies was probably the motive for Longmans to take over the publishing rights to Plutology in 1878 - no doubt to the relief of Macmillan. How many were printed in this run (if there was one at all?) remains unknown, and, like La Nauze, I have never seen a copy of Plutology with the Longmans' imprint (ibid:94-5). La Nauze has certainly proven beyond question that this reprint was not a second edition, as Edgeworth once mistakenly claimed (ibid).

* School of Business, Australian Catholic University, St Patrick's Campus, Locked Bag 4115 DC, Fitzroy, Victoria, Australia 3065. Email: G.Moore@patrick.acu.edu.au. I would like to thank John King and two anonymous referees for their valuable comments on earlier drafts of this paper.

\section{Letter 1: Arthur Housten to Professor Webb ${ }^{7}$}

The Hearn Papers, Melbourne University.

46 T.C.D. Dec. 1863

Dear Webb

I have taken a hurried glance over Hearn's Plutology \& the general impression it makes on my mind is very favourable. The arrangement seems excellent, \& such of the chapters I have had time to read through, deal with their subjects in a manner 
that leaves little to be desired. The style is clear, simple \& devoid of unnecessary technicalities, a quality which would render it particularly agreeable to use. The chapter on the efficiency of labour strikes me as admirable, so does the opening chapter, but this may be partly accounted by the fact that it puts forward in clear \& forcible terms the very ideas with which I am myself in the habit of introducing the study of the Science to $[1 \text { years }]^{8}$ - without the ?. As to the name Plutology I fear it labours under the defect that, according at least to its derivation, it would restrict the Science to the consideration of that very limited portion of wealth which consists of Gold \& Silver. At least it would not include that important portion which consists of that not usually esteemed precious, the ordinary food, clothing shelters of which so large a part of the national wealth consists. Besides it would certainly exclude immaterial wealth which Mr Hearn most properly and expressly includes. Nevertheless if a new title were now to be sought, I do not know one more unobjectionable, or at least less objectionable, than that which he has adopted from the French. I wonder whether Mr Hearn has read our friend Cairnes's Definition \& Logical method of Political Economy. He seems doubtful whether the limits of the Science are accurately fixed. In my mind Cairnes's definition as given in the little work above alluded to completely settles this question. On the whole, Plutology seems to me the best systematic treatise on Political Economy extant \& next to J.S. Mill's Elements \& it is from its conciseness and clearness a valuable addition to the literature of the Science. I intend to read it more carefully at my leisure, but as you asked for my opinion I intended to give it to you.

A Housten.

Professor Webb

34 College

\section{Letter 2: T.E.C. Leslie to Macmillan \& Co. ${ }^{9}$}

The Hearn Correspondence, Australian National Archives.

\section{February 1864}

22 Old Square Lincoln's Inn

Sir,

I beg to thank you for the transmission of Mr Hearn's Plutology, \& I shall also write an acknowledgment to the author.

The volume was sent to the Queen's College Belfast in which I hold a professorship.

I am your [obedient? $]^{10}$ servant,

T.E.C. Leslie. 


\section{Letter 3: Herbert Spencer to Macmillan \& Co. ${ }^{11}$}

The Hearn Correspondence, Australian National Archives.

29 Bloomsbury Sq WC

March 8th 1864

I have to acknowledge, with thanks, the copy of Mr Hearn's 'Plutology' which you have sent me at his request. From the table of contents I judge that it contains much matter which will interest me.

Your [obedient?] [servant?] $]^{12}$

Herbert Spencer

\section{Letter 4: Neilson Hancock to Macmillan \& Co. ${ }^{13}$}

The Hearn Correspondence, Australian National Archives.

14 Gardiner St

March 9th 1864

Sir

Dr Hancock wishes me to acknowledge the receipt of the two copies of Professor Hearn's Plutology \& he begs you will convey to him his thanks.

Yours truly

$\left[\right.$ Fannie?] ${ }^{14}$ Hancock

\section{Letter 5: John Kells Ingram to Macmillan \& Co. ${ }^{15}$}

The Hearn Correspondence, Australian National Archives.

Trinity College

Dublin

March 141864

Sir

I beg to acknowledge the receipt of a copy of Professor Hearn's 'Plutology' forwarded to me through Messrs [indecipherable] \& [indecipherable].

Yours faithfully

John K.Ingram

[H. indecipherable] 


\section{Letter 6: Macmillan \& Co to George Robertson. ${ }^{16}$}

The Hearn Correspondence, Australian National Archives.

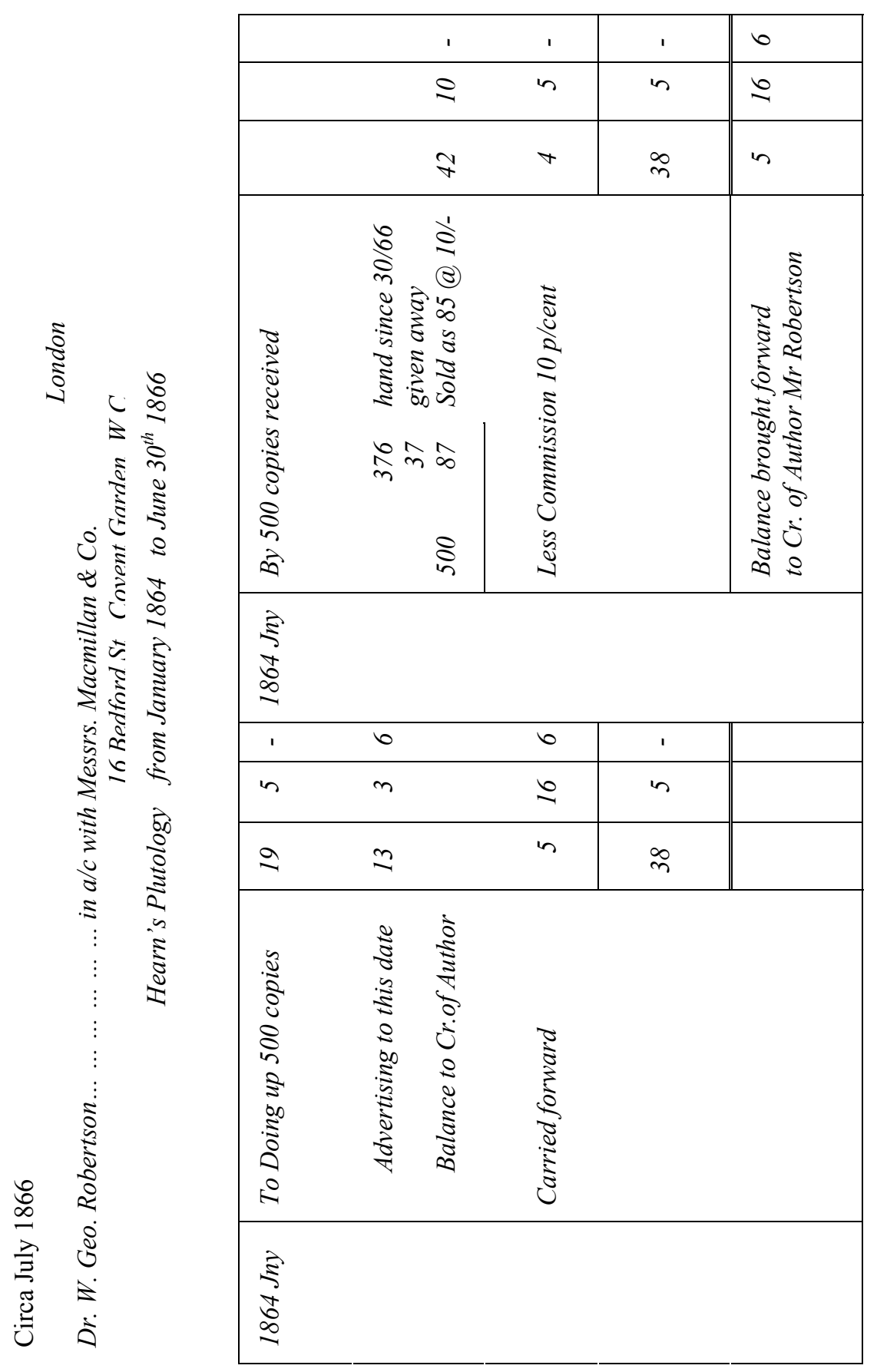




\section{Letter 7: Alexander Macmillan to William Edward Hearn. ${ }^{17}$}

The Hearn Correspondence, Australian National Archives.

Macmillan and Co

Publishers to the University of Oxford

16 Bedford Street, Covent Garden, W.C.

London, Oct: 31. 1866.

My dear Sir,

You must think me very negligent in not writing to you earlier respecting the sale of your book 'Plutology' which you were so kind to commit to our care. The real state of the case has been that its success has been so slight that I have felt reluctance in conveying to you the intelligence that can hardly do otherwise than disappoint you: and I have been constantly hoping that some turn of public opinion and appreciation might take place that would give another [aspect?] ${ }^{18}$ to the sales. Indeed a pleasing note did come to me when I found that Mr Stanley Jevons in his book on the Coal Question which made a considerable stir in the Political \& commercial world last season, spoke in very warm terms of your book in a note to his. This paragraph I had [excised?] ${ }^{19}$ and appended to advertisements in some of the more influential newspapers \& conspicuously in our own magazine. But the effect has been slight indeed, almost nothing, and this though Mr Jevons was in the meantime elected to the chair of Political Economy at Owens College Manchester, which ought to have added weight to his very favourable judgement. I have endeavoured to elicit opinions from such of the leading Political Economists to whom I sent copies, and whom I knew personally. The only definite one I got was verbally from a man of considerable weight in the current of opinion on such subjects in this country that he did not agree in Professor Jevons estimate. I hear it is hard for an outsider to fall into the ranks here- perhaps any where. I was in hopes that you have heard from J.S. Mill or others. Mr [Blanch?] ${ }^{20}$ sent them copies as soon as they were published. I will still take any opportunity I may have of calling attention to your book. At present the only ally I know is Mr Jevons, and he is still young and not very influential, but he is steadily working his way.

Your kind communication respecting another work on the English Constitution I received some time since. But you understand that my reply to it naturally could be influenced by the success of your first book, and you will naturally judge that I could hardly encourage you to publish, or myself feel justified in undertaking a new work the general character of which resembles so nearly the other and the condition of the success of which must in all respects be so similar. Questions of Political Economy and Constitutional Government are moving very much in the light of current facts at home and ideas are modified by these facts, in almost imperceptible and yet important degrees, or at least held to be important. Hence I fear the constant liability to any writing from the colonies that is not on some very large question not having a somewhat provincial air. I don't know whether I am at all right in my conjecture as to the cause of the non-success. But it has struck as possible. I wonder whether you are at all in direct communication with any of our Political Economists on the subjects that interest you. I think you 
would do well to communicate with Professor Jevons. His address is Owens College, Manchester.

With best regards I am,

[?] [?] $]^{21}$

Yours faithfully,

A. Macmillan

\section{Letter 8: John Kells Ingram to William Edward Hearn.}

The Hearn Correspondence, Australian National Archives.

Trinity College, Dublin

Nov 141865

Dear Professor Hearn,

The bearer of this note, Dr Corrigan, ${ }^{22}$ was my pupil during his undergraduate course in this College, and I know him intimately, and sincerely [indecipherable] him, ever since. He has obtained an important governmental appointment, in connexion with the Wesleyan body, in your colony; and I take the liberty of furnishing him with this introduction to you-I should feel much obliged to you if you would give him such information as your local experience enables you to supply; and assist him in any other way which may be in your power, at his entrance in his new sphere.

I have to thank you for the gift of your 'Plutology', which came to me from the Publisher. I was much struck with the [indecipherable] of your treatment of the subject; and with the great variety of novel and interesting facts you have brought together in 'verification' or illustration of the theory.

[indecipherable] [indecipherable]

Yours very truly

John K. Ingram

\section{Letter 9: T.W. Moffet to William Edward Hearn. ${ }^{23}$}

The Hearn Papers, Melbourne University

Queen's College

Galway

$25^{\text {th }}$ August 1887

My Dear Hearn

You will doubtless think it strange to receive a letter from me after so long and what may seem an unaccountable silence; but at the same time I have no doubt that you will accept my assurance that I have never ceased to cherish for you the same 
affectionate regard and esteem which I began to feel some forty years ago: 'There! Progress'.

I do think [indecipherable] now that when I was preparing for entrance with Trinity College, my old teacher said to me one day-'You will never feel the beauty of that Ode until you have passed your sixtieth year', how incredibly short the interval now appears!

I could not say how often I have proposed to sit down and write to you a long letter, but deferred it from day to day; and indeed I believe no other in the land has had a more laborious life than mine for many years. I have however had opportunities for hearing about you from various quarters, and I need not say I was quite prepared to hear of the high position and authority you possess in the land of your adoption; but I have often thought that if you had remained at home - and proceeded to the profession which you originally contemplated, you would have unquestionably reached the highest eminence; but no doubt it has been ordered right.

I take the whole [indecipherable] blame to myself for not having written, because you several times presented me with most gratifying tokens of your continued remembrance. I have received your three books which may well be called great works, from the knowledge, the mental grasp, and the power they display. Two of them at least I have thoroughly studied and frequently refer to in my lectures (you are aware that since 1864 the Chair of History and English Literature has been combined with that of Logic and Metaphysics). It was not later than yesterday that I had occasion to call the attention of a young friend to your 'Government of England': I speak of Mark Lynch, (the grandson of our old friend P.M. Lynch) who is going up for his degree at Oxford in the [Victorian?] ${ }^{24}$ group. The very last occasion I dined in Trinity College I was speaking to some of the Fellows about these books. I hope you will not think I am affecting patronage. I merely wish to show that you and your books are not forgotten by me.

You no doubt are in the habit of reading English and Irish papers; but I am sure you will not the less be glad to hear about the old friends and the old places.

Our old friend Mr Berwick died in March 1877. He had sustained two heavy blows-the first, the loss of his Brother (Judge Berwick) and his sister in that deplorable catastrophe of the burning Railway Train in Wales, and subsequently the death of his only child to whom he was devotedly attached. After the last event life did not appear to possess much interest for him. To cheer him, I usually came in to [see? $]^{25}$ him here (I was then Registrar of the College) and spent a couple of hours with him every evening. On his last evening, I took leave of him at Ten O'Clock, as usual; and his last words to me, making an engagement for the next day, were'Well, to-morrow at Eleven; Gloss bless you!' That same night he passed instantaneously and quietly away in his sleep. I did not apply for the vacant office; of course, I would have done so, if there had been time; but the Lord Lieutenant (the Duke of Marlborough) sent for me, and told me he had written to the Home Secretary, requesting him to recommend me to the Queen. I hold together with the Presidentship my old professorship, so, as you may well believe, I have had a very busy life.

Only two of the men who came here with us now survive - Dr Colahan who resigned his Chair some years ago; he is blind and very feeble; and Dr Browne who is still Professor of Surgery, but at present very infirm. Mulcahy passed away before you left: his successor [Altman?] ${ }^{26}$ is still here: a very eminent mathematician, lately elected F.R.S. 
Hugh Law, who had reached the highest eminence at the Bar, and was highly respected in the House of Commons died Lord Chancellor of Ireland. Galway.

Caulfield [Heron? $]^{27}$ dropped dead while in the act of fishing here in

$\operatorname{Dr}[\mathrm{B} \text { ? }]^{28}$ died suddenly at a Railway Station in Belgium.

Doherty, who became possessor through his wife of a large estate in Donegal, but who still retained his Chair, also died suddenly: the same was the fate of Skilling.

I now come to our old and dear friend [Nesbitt? $]^{29}$. You are aware that he was transferred to Belfast as Professor of Latin. Some years after he undertook in addition the office of Librarian. You remember he had not a strong constitution, while at the same time he was a most conscientious and laborious worker. He came to me on a visit a couple of months before his death; and I observed that the work was telling heavily on him, and I entreated him to resign the Librarianship. From anxiety to make provision for his family, he held on, and there can be no doubt that he sacrificed health and life to parental love. His wife, Miss Alexander died many years before him: his sister, who married John E. Cairnes survives. Cairnes died universally respected and lamented.

William King and his wife are also gone. One of their sons is the head of the Geological Department in India; the other holds high office in Ceylon.

I should have mentioned that Melville resigned a few years ago: he did not leave behind him a single friend in Galway!

Mahony became an inspector at National Schools, and died after a lingering illness.

Croker King is now one of the Commissioners of the Local Government Board. I usually see him whenever I visit Dublin: he and his wife are almost as young as ever; they are certainly as fond of social life, and are as kind and hospitable as in the old days: their John, whom you remember as a child, is now a retired Lieutenant-Colonel.

Ronald received through his wife a large fortune, and now lives retired near Edinburgh.

For myself - I lost my dear Wife in 1874. I married again in 1876. I enclose a photograph taken last year which will show you the change that time has made. I had hoped to send one of my wife, which - as there is not one at present left, I shall defer until next post.

It is now time to ask about yourself: I trust that during these years you have been enjoying as much happiness as one might expect in life. I shall be gratified if you will favour me with a letter and I should be much obliged if you would give us a return of portraits.

You are of course aware of the vast changes that have been made in our University system, and how injuriously it has affected the Queen's College. I send you herewith a copy of a recent Report of mine, which will put you in possession of the facts.

The Royal Galway Institution exists, but it is not to (sic) active in the way of Lectures as in the old times. I delivered two lectures (on Oratory) in the course of the last fifteen.

Many of your old contemporaries in Trinity College have passed away: Evelyn, Finch White, Wilson, Barnes, Graves, Mayne. 
I send herewith a Galway Newspaper which gives you an account of a lamentable accident by which the sons of two of our Professors have just lost their lives.

With vivid memories of 'Auld Lang Syne' I am forever, my dear Hearn, your faithful friend.

\section{T.W. Moffett}

\section{Notes}

1 It should be noted, however, that Groenewegen and McFarlane (1990:55-6) have carefully re-appraised La Nauze's pioneering (though sometimes unbalanced) assessments of Hearn's originality and importance. See also Wakatabe (2001) on the issue of whether or not Hearn was a plagiarist.

2 It must be stressed that none of the aforementioned historical authorities actually states that Plutology was a publishing success. Nearly all of them nonetheless dwell on the glowing contemporary references to this book in such a way that the unwary reader is in danger of incorrectly inferring that Plutology was, in some small way, a success in the market-place. Green, for example, states that 'Plutology has a definite place, if not amongst the highest, in the history of economics' and then cites some of the contemporary references listed in the main text above (1961:I, 322); Blainey states that Plutology was 'less original, but sufficiently fresh in its method and approach to earn the high praise of Jevons, Marshall, and the foremost economists of Britain' (1957:41); La Nauze wrote that a 'survey of opinion shows that Hearn's work gained acceptance as amongst the best in its kind judged by the highest contemporary standards', before qualifying this commendation somewhat by embarking on what can only be described as a pathological search for traces of plagiarism in Hearn's work (1949:49); and Copland lists the contemporary British references before stating that 'Hearn has an accepted place in the history of economic thought' (1935:18). Only the ever thorough Groenewegen and McFarlane (1990) comment on the publishing success of the book. Specifically, although they state that Hearn is "clearly the most famous Australian nineteenth century academic economists because his book, Plutology, gained him a considerable reputation in the English speaking world as a useful textbook', they also point out in passing that it could not have been a commercial success in Australia (England is not mentioned), since there was a limited market for university political economy texts in Australia (1990:51, 64).

3 I have assumed that the letters sent to Hearn via Macmillan were actually received by Hearn because all of these letters were amongst the rest of Hearn's correspondence held at the National Library of Australia. I nonetheless cannot discount the possibility that the private collector who originally acquired this correspondence simply placed all of the letters relating to Hearn (not just those that were actually received by Hearn) in the same manuscript folder. I would like to thank an anonymous referee for pointing this out to me. It also should be emphasised that there is some correspondence between J.F. Herschel and Hearn relating to the appropriateness of the title of Plutology, but this has already been published (Treloar and Pullen 1998), and hence is not printed in the appendix attached to this note.

4 The correspondence between Hearn and his Irish contemporaries calls for a qualification to a passage in Moore (2001:108), in which it is stated that 'there appears to be no extant correspondence between Hearn and his undergraduate colleagues'. Fortunately, a later passage from the same paper states that 'no doubt other links between Hearn and those from his undergraduate years will surface in time' (ibid:109). 
5 It is possible that either John Elliot Cairnes or Mill was the (noxious) authority who verbally disagreed with Jevons's estimate. This inference is based on Mill's published correspondence (Mineka and Lindley 1972: vol 15), which implies that Cairnes actively discouraged Mill from responding to Macmillan's request to puff Plutology. Specifically, in a letter written shortly after the appearance of two reasonably positive notices of Plutology in The Reader and The Spectator, Mill appears to accept Cairnes's judgement that the reviewers were not competent and that book was not worth reading: 'Plutology has been sent to me, but I have not yet had time to look into it, and shall now think many other duties more urgent than that of reading it. I should ascribe the opinion given of it by the Spectator and Reader not to defects of honesty, but to sheer ignorance and incompetence on the subject' (ibid: March 281864 letter 684). The review for The Reader was signed L.S., and in a subsequent letter to Cairnes Mill wrote: 'I also suspect that L.S. is Leslie Stephen, but as I have no proof of his knowledge of the subject, and great proof of yours, I have little doubt that he has in this case shewn ignorance of it' (ibid: April 2, 1864 letter 688).

6 The review signed L.S. in The Reader was the most extensive of the early appraisals of Plutology, but it is not cited in the standard secondary literature on Hearn (see, however, Mineka and Lindley 1972: vol 15: April 2, 1864 letter 688), no doubt because The Reader was a short-lived magazine that is now extremely rare. As suggested by Mill in footnote 5 above, this review was almost certainly written by Leslie Stephen. It is known, for example, that Stephen often signed his initials L.S. at the base of his articles; that he was writing other reviews of economic works at this time; and that he was unsuccessfully approached by the proprietors of The Reader to become the editor in 1862 and 1865 .

7 Arthur Housten (1833-1914) held the Whately chair at Trinity College Dublin from 1861 to 1866 . It is likely (but by no means certain) that the Professor Webb whom Housten is addressing is either George Henry Frederick Webb or Thomas Prout Webb. The former was briefly a lecturer in law at Melbourne University who eventually became a QC and then a Supreme Court judge. The latter entered Melbourne University in 1863, studied arts and law under Hearn (and thereby could have been working as some sort of research assistant for Hearn in 1863), collaborated with Hearn on the codification of Victorian law and also eventually became a QC. The conjecture that the Webb in question was either one of these two lawyers is partly drawn on the basis of two additional letters in the Hearn Correspondence. The first is a letter from Thos (presumably Thomas Prout) Webb to Hearn, dated 1 November 1867, acknowledging the receipt of Hearn's Government of England, and the second is a letter from the Crown Law Offices to Hearn, dated 17 April 1884, stating that the Crown solicitor has been instructed to brief a Mr Webb, QC, as requested by Hearn.

8 The words are unclear.

9 T.E. Cliffe Leslie (1826-1882) held the Chair of Jurisprudence and Political Economy at Queens College, Belfast, from 1853 to 1882 and became the leading English historical economist in the 1870s.

10 The word is unclear.

11 Herbert Spencer (1826-1903) was a philosopher and pioneer of evolutionary sociology in mid-Victorian Britain. Since Hearn was one of the first political economists to conceive society and its economic relations as an evolving organism, and since he cites Herbert Spencer's work in this field (1864:398), it is not surprising that a copy was sent to Spencer.

12 The words are unclear.

13 Neilson Hancock (1820-1888) held the Whately Chair at Trinity College Dublin from 1846 to 1851 . 
14 The word is unclear.

15 John Kells Ingram (1823-1907) held various academic posts at Trinity College, Dublin, from 1843 to 1907 , and is now chiefly remembered by economists for his highly successful History of Political Economy (1888).

16 George Robertson was the Australian distributor of Plutology.

17 Alexander Macmillan was the English distributor of Plutology.

18 The word is unclear.

19 The word is unclear.

20 The word is unclear.

21 The words are unclear.

22 I have been unable to identify Dr Corrigan.

23 Thomas W. Moffet was Professor of Logic and Metaphysics at Queens College, Galway, and occasional Barrington Lecturer in Political Economy.

24 The word is not clear.

25 The word is unclear.

26 The word is unclear.

27 The word is unclear.

28 The word is unclear.

29 The word is unclear.

\section{References}

\section{Unpublished Material}

The Hearn Correspondence, Australian National Archives.

The Hearn Papers, Melbourne University.

J.A. La Nauze Papers, Melbourne University.

\section{Published Material}

Black, R.D.C. (ed.). 1973-81. Works and Correspondence of William Stanley Jevons. Macmillan. London.

Blainey, G. 1957. A Centenary History of the University of Melbourne. Melbourne University Press. Melbourne.

Copland, D.B. 1935. W.E. Hearn. The First Australian Economist. Melbourne University Press. Melbourne.

Edgeworth, F.Y. 1896. 'William Edward Hearn (1826-1888)'. Printed in Palgrave's Dictionary of Political Economy. Vol II. Macmillan. London. p. 295.

Green, H.M. 1961. A History of Australian Literature. Pure and Applied. Angus and Robertson. Melbourne

Groenewegen, P. and B. McFarlane. 1990. A History of Australian Economic Thought. Routledge. London.

Hearn, W.E. [1863] 1864. Plutology. Macmillan. London..

Hearn, W.E. 1867. The Government of England. George Robertson. Melbourne.

Hutchison, T.W. 1953. A Review of Economic Doctrines, 1870-1929. Clarendon Press. Oxford.

Jevons, W.S. 1864. 'Review of W.E. Hearn's Plutology'. The Spectator. March 5. p. 276. 
Jevons, W.S. [1865] 1906. The Coal Question. An Inquiry Concerning the Progress of the Nation, and the Probable Exhaustion of Our Coal Mines. Macmillan. London.

Jevons, W.S. 1871. The Theory of Political Economy. First ed. Macmillan. London and New York.

Jevons, W.S. [1879] 1931. The Theory of Political Economy. Fourth ed. Macmillan. London.

La Nauze, J.A. 1949. Political Economy in Australia. Historical Studies. Melbourne University.

Mineka, F.A. and D. Lindley (eds). 1972. The Late Letters of John Stuart Mill 1949-1873. Toronto University Press. Toronto. Vol. 15.

Moore, G.C.G. 2001. 'An Irish clerisy of political economists? Friendships and enmities amongst the mid-Victorian graduates of Trinity College, Dublin'. History of Economic Review 33, Winter, pp 102-111.

Wakatabe, M. 2001. 'William Edward Hearn on knowledge-based growth: innovator, or plagiarist of John Rae?'. History of Economics Review 33, Winter, pp 64-80. 